\title{
National recommendations for \\ anticoagulant thromboprophylaxis in \\ children and adolescents with SARS-CoV-2 infection
}

Barbara Faganel Kotnik, Alenka

Trampuš Bakija, Tadej Avčin, Lidija

Kitanovski

\section{Izvleček}

Akutno okužbo s SARS-CoV-2 lahko zaradi aktivacije koagulacijske poti spremljajo hiperkoagulabilno stanje s trombemboličnimi dogodki (TED), z okužbo s SARS-CoV-2 povezana koagulopatija in diseminirana intravaskularna koagulacija. Dva do šest tednov po preboleli okužbi se pri otrocih lahko razvije večsistemski vnetni odziv, pri katerem je tveganje TED ponovno povečano zaradi vsesplošne poškodbe žilnega endotela ter delovanja številnih koagulacijskih in vnetnih dejavnikov.

Predstavljamo nacionalna priporočila za farmakološko antikoagulacijsko tromboprofilakso otrok in mladostnikov $z$ okužbo s SARS-CoV-2, ki se zdravijo ambulantno, v bolnišnici ali v enoti intenzivne terapije. Ločeno smo opredelili obravnavo otrok in mladostnikov s prirojeno motnjo strjevanja krvi, znano prirojeno trombofilijo in vstavljenim centralnim venskim katetrom.

Ključne besede: SARS-CoV-2, antikoagulantna profilaksa, otroci.

\begin{abstract}
Acute SARS-CoV-2 infection may be accompanied by a hypercoagulable state with thromboembolic events, SARS-CoV-2-associated coagulopathy, and disseminated intravascular coagulation due to activation of the coagulation pathway. Two to six weeks after infection, children may develop a multisystem inflammatory response when the risk of thromboembolic disease is again increased due to widespread vascular endothelial damage and numerous coagulation and inflammatory factors.

We present national recommendations for pharmacological anticoagulant thromboprophylaxis in children and adolescents with SARS-CoV-2 infection as outpatients, in hospital or in the intensive care unit. Treatment of children and adolescents with congenital bleeding disorders, known congenital thrombophilia and inserted central venous catheter is specified separately.
\end{abstract}

Key words: SARS-CoV-2, anticoagulant prophylaxis, children. 


\section{Uvod}

Med okužbo s SARS-CoV-2 se lahko kot del vnetnega odziva gostitelja za zamejitev virusne okužbe aktivirajo koagulacijske poti. Tako lahko covid-19 spremljajo hiperkoagulabilno stanje s trombemboličnimi dogodki (TED), z okužbo s SARS-CoV-2 povezana koagulopatija in diseminirana intravaskularna koagulacija (DIK) (1).

V nasprotju s klasičnim DIK so za koagulopatijo, povezano z okužbo s SARS-CoV-2, ki je pri otrocih manj pogosta kot pri odraslih, značilne povišane vrednosti fibrinogena in D-dimera, blago znižane vrednosti trombocitov (št. trombocitov $100 \times 10 \% /$ ) ter blago podaljšane vrednosti protrombinskega časa (PČ) in aktivirani parcialni tromboplastinski čas (APTČ) (1). Omenjena odstopanja laboratorijskih preiskav so običajno sorazmerna s povečanimi vrednostmi kazalnikov vnetja, kot je CRP (2). Znaki, značilni za mikroangiopatijo, so $v$ akutni fazi okužbe pri otrocih prav tako manj pogosti kot pri odraslih (3). $\vee$ redkih primerih težkega poteka okužbe s SARS-CoV-2 $z$ večorgansko odpovedjo se razvije koagulopatija, značilna za očiten DIK, opredeljen z merili Mednarodnega združenja za trombozo in hemostazo (angl. International Society on Thrombosis and Haemostasis, ISTH): srednje težka do težka trombocitopenija (št. trombocitov < $50 \times 10^{9} /$ l), podaljšane vrednosti PČ in APTČ, izrazito povišane vrednosti $D$-dimera in znižane vrednosti fibrinogena $(<1,0 \mathrm{~g} / \mathrm{l})(4)$.

Dva do šest tednov po preboleli okužbi s SARS-CoV-2 se pri otrocih lahko razvije večsistemski vnetni odziv (angl. multisystem inflammatory syndrome in children, MIS-C), ki ga opredeljujejo povišana telesna temperatura in zvišane vrednosti laboratorijskih kazalnikov sistemskega vnetja, kožne spremembe, gastritis/kolitis in srčne manifestacije, vključno z miokarditisom in/ali koronarnim arteritisom, ki spominja na Kawasakijevo bolezen (5-8). Zaradi vsesplošne poškodbe žilnega endotela, pogoje- ne s pretiranim imunskim odzivom, ter aktivacije trombocitov in faktorjev strjevanja krvi, upočasnjene fibrinolize in številnih drugih koagulacijskih in vnetnih dejavnikov je v tem obdobju bolezni povišano tveganje za TED (8-10).

Glede na pomanjkanje enotnih mednarodnih smernic za antikoagulantno (AK) tromboprofilakso pri otrocih in mladostnikih z okužbo s SARS-CoV-2 smo na podlagi pregleda literature, $\mathrm{ki}$ se nanaša na obravnavo odraslih oseb in otrok z okužbo s SARS-CoV-2, in glede na lastne klinične izkušnje pripravili sledeča nacionalna priporočila za farmakološko AK tromboprofilakso otrok in mladostnikov z okužbo s SARS-CoV-2.

Predstavljena priporočila so namenjena otrokom in mladostnikom, ki so zaradi covid-19:

- vodeni ambulantno;

- hospitalizirani zaradi drugih bolezni, a imajo hkrati brezsimptomno ali simptomatsko okužbo s SARS-CoV-2 z blagimi simptomi;

- hospitalizirani zaradi simptomatske okužbe s SARS-CoV-2 na navadnem oddelku;

- hospitalizirani zaradi simptomatske okužbe s SARS-CoV-2 v enoti za intenzivno terapijo;

- hospitalizirani zaradi MIS-C.

Glede na posebnosti smo ločeno opredelili obravnavo otrok in mladostnikov:

- s prirojeno motnjo strjevanja krvi (MSK),

- z znano prirojeno trombofilijo,

- z vstavljenim centralnim venskim katetrom (CVK).

Pričakujemo, da se bodo napisana priporočila posodabljala.

\section{Obravnava otrok z} okužbo s SARS-CoV-2, obravnavanih ambulantno

Otroci, ki zaradi okužbe s SARS-CoV-2 ne potrebujejo bolnišničnega zdravljenja, ne potrebujejo farmakološke AK tromboprofilakse.
Obravnava otrok s

covid-19, ki so brez

simptomov in potrebujejo

bolnišnično zdravljenje

zaradi drugih bolezni

Farmakološke AK tromboprofilakse ne predpisujemo rutinsko pri otrocih z brezsimptomnim potekom covid-19 ali s simptomatskim potekom covid-19 z blago izraženimi simptomi, ki zahtevajo bolnišnično zdravljenje zaradi drugih vzrokov, če nimajo nameščenega stalnega CVK in če nimajo štiri ali več kliničnih dejavnikov tveganja TED (Tabela 1) (11), saj tveganje klinično pomembnih krvavitev pri večini brezsimptomnih otrok verjetno prevlada nad potencialnimi koristmi preprečevanja TED (Tabela 2).

\section{Obravnava otrok, ki potrebujejo bolnišnično zdravljenje zaradi simptomatske okužbe s SARS-CoV-2 na običajnem oddelku}

Poročajo, da je imela večina otrok, ki je $v$ bolnišnici utrpela TED, več kot en dejavnik tveganja za trombozo (13). Ker ima lahko otrok, ki preboleva simptomatsko okužbo s SARS-CoV-2, pridružene tudi dodatne pridobljene protrombotične dejavnike, moramo pri otrocih, ki zaradi simptomatske okužbe s SARS-CoV-2 potrebujejo bolnišnično zdravljenje ob sprejemu, vsakodnevno klinično in laboratorijsko ocenjevati tveganje za TED in DIK (Tabeli 1 in 4) ter ob odsotnosti kontraindikacij razmisliti o uvedbi farmakološke AK tromboprofilakse, (Tabela 3).

Določiti moramo hemogram, APTČ, PČ, TČ, fibrinogen, antitrombin (AT) in D-dimer, ki je pomemben kazalnik tveganja TED, če je povišan petkrat nad pražnimi vrednostmi. 
Če ima otrok pridružene kronične bolezni, svetujemo posvet s specialistom ustrezne stroke.

Dejavnike tveganja za TED, ki jih upoštevamo pri odločitvi za farmakološko AK tromboprofilakso, smo priredili po lokalnih priporočilih ameriške bolnišnice Children's Hospital Colorado (14) in pediatrično-neonatalnega pododbora ISTH ter jih navajamo v Tabeli 1 (11). Priporočila Children's Hospital Colorado svetujejo uvedbo farmakološke AK tromboprofilakse pri pomembni osebni ali družinski anamnezi TED (Tabela 3) ali ob prisotnosti štirih ali več dejavnikov tveganja za TED, če otrok nima vstavljenega CVK. Glede na priporočila ISTH, ki pri odločanju o profilaksi ne upoštevajo določenega števila dejavnikov tveganja za TED, temveč jih le naštevajo, menimo, da moramo do pridobitve več izkušenj ob sprejemu otroka ali mladostnika razmisliti o uvedbi farmakološke AK tromboprofilakse po posvetu s hematologom, ki za posameznega bolnika oceni tveganja in koristi profilakse/ zdravljenja (glej Tabeli 1 in 3). Po razpravljanju o starostni meji za predpis farmakološke AK tromboprofilakse so kot mejno starost določili 12 let, ki običajno pomeni pričetek pubertetnega razvoja.

\section{Obravnava hospitaliziranega otroka s simptomatsko okužbo SARS-CoV-2 v enoti za intenzivno terapijo}

Obravnava otroka, ki je hospitaliziran zaradi simptomatske okužbe s SARS -CoV-2 v enoti za intenzivno terapijo, naj poteka $v$ medsebojnem sodelovanju pediatra intenzivista, infektologa, imunologa in hematologa. Vsakodnevno klinično in laboratorijsko spremljamo morebiten razvoj zapletov.

$\checkmark$ odsotnosti kontraindikacij za farmakološko AK tromboprofilakso moramo razmisliti o uvedbi intenziviranega profilaktičnega odmerka nizkomolekularnega heparina (NMH), ki ga odmerjamo vsakih 12 ur za zago-
Kontraindikacije za antikoagulantno

tromboprofilakso/zdravljenje
Dejavniki tveganja za trombozo

- starost > 12 let

- osebna anamneza trombofilije ali TED

- sorodnik v prvem kolenu s TED

prisotnost centralnih venskih katetrov s prehodnimi trombozami ali brez njih

zmanjšana pomičnost od pričetka bolezni

opekline

aktivna onkološka bolezen

sum na vensko stazo ali stanje nizkega

srčnega pretoka

zdravljenje z estrogeni

aktivna sistemska okužba

nefrotski sindrom

zagon cistične fibroze

zagon sistemske vnetne bolezni

prekomerna prehranjenost (ITM > 95. P)

huda dehidriranost

nedavna operacija ali poškodba

\section{Absolutne:}

- aktivna krvavitev

- z zdravili povzročena trombocitopenija $\left(\leq 50 \times 10^{9} / \mathrm{l}\right)(12)$

- lumbalna punkcija/oftalmološki/ nevrokirurški poseg znotraj 24-72 ur

Relativne:

- nenadzorovana arterijska hipertenzija

motnja strjevanja krvi

anamneza razjede na želodcu

diabetična retinopatija

- ledvična disfunkcija (nevarnost akumulacije heparina - potrebna prilagoditev zdravljenja)

morebitna prisotnost umetne zaklopke,

ker bolniki prejemajo bolj učinkovito AK zdravljenje $z$ višjimi tarčnimi vrednostmi PČ-INR
TABELA 1. DEJAVNIKI TVEGANJA ZA TROMBOZO IN KONTRAINDIKACIJE ZA ANTIKOAGULANTNO TROMBOPROFILAKSO IN/ALI ZDRAVLJENJE (11).

TABLE 1. RISK FACTORS FOR THROMBOSIS AND CONTRAINDICATIONS FOR ANTICOAGULANT THROMBOPROPHYLAXIS AND/OR TREATMENT (11).

Legenda: ITM - indeks telesne mase; TED - trombembolični dogodek.

\begin{tabular}{lll} 
& $\begin{array}{l}\text { Dejavniki tveganja za } \\
\text { TED, nepovezane z } \\
\text { okužbo s SARS-CoV-2 }\end{array}$ & $\begin{array}{l}\text { Antikoagulantna } \\
\text { tromboprofilaksa }\end{array}$ \\
\hline $\begin{array}{l}\text { Hospitalizirani zaradi drugih vzrokov s } \\
\text { hkratno brezsimptomno ali blago okužbo } \\
\text { s SARS-CoV-2 }\end{array}$ & $\geq 4$ & da \\
\cline { 2 - 3 } & $<4$ & ne \\
\hline
\end{tabular}

TABELA 2. OBRAVNAVA OTROK, KI POTREBUJEJO BOLNIŠNIČNO ZDRAVLJENJE ZARADI DRUGIH VZROKOV, S HKRATNO BREZSIMPTOMNO OKUŽBO S SARS-COV-2 ALI SIMPTOMATSKIM POTEKOM COVID-19 Z BLAGO IZRAŽENIMI SIMPTOMI.

TABLE 2. TREATMENT OF CHILDREN HOSPITALISED FOR OTHER CAUSES WITH CONCOMITANT ASYMPTOMATIC SARS-COV-2 INFECTION OR A SYMPTOMATIC COURSE OF COVID-19 WITH MILD SYMPTOMS. Legenda: TED - trombembolični dogodek. 


\begin{tabular}{|c|c|c|c|}
\hline & D-dimer $>5$-krat $\uparrow$ & $\begin{array}{l}\text { Dejavniki tveganja za } \\
\text { TED, nepovezane z } \\
\text { okužbo s SARS-CoV-2 }\end{array}$ & $\begin{array}{l}\text { Antikoagulantna } \\
\text { tromboprofilaksa }\end{array}$ \\
\hline \multirow{3}{*}{$\begin{array}{l}\text { Hospitalizirani zaradi } \\
\text { simptomatske okužbe } \\
\text { s SARS-CoV-2 }\end{array}$} & da & $l^{*}$ & da \\
\hline & \multirow{2}{*}{ ne } & $\geq 1$ & da \\
\hline & & ne & ne \\
\hline
\end{tabular}

TABELA 3. OBRAVNAVA OTROK, HOSPITALIZIRANIH ZARADI SIMPTOMATSKE OKUŽBE S SARS-COV-2. TABLE 3. TREATMENT OF CHILDREN, HOSPITALISED FOR SYMPTOMATIC SARS-COV-2 INFECTION. Legenda: /* antikoagulacijsko tromboprofilakso uvedemo ne glede na dejavnike tveganja za TED; \# posvet s hematologom; TED - trombembolični dogodek; PČ - protrombinski čas; s - sekunda.

\begin{tabular}{|c|c|c|c|c|c|c|c|}
\hline $\begin{array}{l}\text { Število } \\
\text { trombocitov } \\
\left(\times 10^{9} / 1\right)\end{array}$ & $\begin{array}{l}\text { Št. } \\
\text { točk }\end{array}$ & D-dimer & $\begin{array}{l}\text { Št. } \\
\text { točk }\end{array}$ & $\begin{array}{l}\text { Podaljšanje } \\
\text { PČ (s) }\end{array}$ & $\begin{array}{l}\text { Št. } \\
\text { točk }\end{array}$ & $\begin{array}{l}\text { Fibrinogen } \\
(\mathrm{g} / \mathrm{l})\end{array}$ & $\begin{array}{l}\text { Št. } \\
\text { točk }\end{array}$ \\
\hline$\geq 100$ & 0 & $\begin{array}{l}\text { blago } \\
\text { povišan }\end{array}$ & 0 & $<3$ & 0 & $\geq 1,0$ & 0 \\
\hline 50 do $<100$ & 1 & $\begin{array}{l}\text { srednje } \\
\text { povišan }\end{array}$ & 2 & 3 do $<6$ & 1 & $<1,0$ & 1 \\
\hline$<50$ & 2 & zelo povišan & 3 & $\geq 6$ & 2 & & \\
\hline
\end{tabular}

TABELA 4. TOČKOVNIK DISEMINIRANE INTRAVASKULARNE KOAGULACIJ (DIK) (JASNA DIK OB SEŠTEV$K U \geq 5)(4)$.

TABLE 4. DISSEMINATED INTRAVASCULAR COAGULATION (DIC) SCORE (CLEAR DIC IF 5 OR MORE POINTS) (4).

Legenda: PČ - protrombinski čas; s - sekunda.

\begin{tabular}{ll} 
Prirojeni trombofilni dejavnik & Tveganje TED \\
\hline mutacija v FV Leiden (G1691A) & $\begin{array}{l}\text { heterozigot: } 3 \text { - do } 5 \text {-krat } \uparrow \\
\text { homozigot: } 50 \text { - do } 80 \text {-krat } \uparrow\end{array}$ \\
\hline mutacija v FII (G20210A) & heterozigot: 3 -krat $\uparrow$ \\
\hline polimorfizem MTHFR C677T & $\uparrow$, če homocistein $>10 \mu \mathrm{mol} / \mathrm{l}$ \\
\hline$\downarrow$ antitrombin & heterozigot: 10 - do 20 -krat $\uparrow$ \\
\hline$\downarrow$ protein C & 10-krat $\uparrow$ \\
\hline$\downarrow$ protein S & 10-krat $\uparrow$ \\
\hline Lp(a) $>300 \mathrm{mg} / \mathrm{l}$ & 7-krat $\uparrow$ \\
\hline
\end{tabular}

TABELA 5. STOPNJA TVEGANJA ZA TROMBOEMBOLIČNI DOGODEK GLEDE NA PRIROJENI TROMBOFILNI DEJAVNIK (22).

TABLE 5. RISK OF A THROMBOEMBOLIC EVENT ACCORDING TO THE SPECIFIC INHERITED THROMBOPHILIC FACTOR (22). tavljanje vrednosti anti-Xa v območju 0,4-0,5 IU/ml. Farmakološka AK profilaksa je indicirana tudi ob potrebi po zunajtelesni membranski oksigenaciji (ECMO) v skladu s priporočili (13).

$\mathrm{V}$ primeru hemodinamsko nestabilne pljučne embolije ali okončino ogrožajoče globoke venske tromboze moramo razmisliti o trombolizi (13). Pri masivni pljučni emboliji ima sistemska tromboliza $z$ alteplazo prednost pred lokalno mehansko trombolizo, upoštevati pa moramo tudi povečano tveganje izpostavitve okužbi s SARS-CoV-2 interventnih radiologov ob transportu in v intervencijskem prostoru (13). Če se odločimo za lokalno trombolizo, ki je indicirana v primeru kontraindikacije za sistemsko trombolizo, svetujemo upoštevanje skupnega stališča, ki ga sprejmejo pediater intenzivist, hematolog in interventni radiolog.

\section{Otroci, ki zaradi okužbe s SARS-CoV-2 prebolevajo večsistemski vnetni odziv (angl. MIS-C)}

Poleg poškodbe endotela in aktivacije koagulacije na tveganje za TED pri otrocih z MIS-C vplivajo tudi sistemsko vnetno stanje, nepomičnost in prisotnost CVK. Ker ima heparin poleg antikoagulacijske vloge tudi protivnetno delovanje (15) ter imunomodulatorni in morda zaščitni učinek na poškodovani endotel žil (16-19), svetujemo uvedbo AK tromboprofilakse pri vseh otrocih z MIS-C, če ni kontraindikacij $(20,1)$.

Pri običajnem poteku MIS-C priporočamo odmerjanje AK tromboprofilakse $z$ $\mathrm{NMH}$ vsakih 12 ur s tarčno vrednostjo anti-Xa 0,2-0,3 IE $/ \mathrm{ml}$, pri težkem poteku, naraščajočih vrednostih D-dimera ali izrazito povišanih vrednosti D-dimera pa odmerjanje AK tromboprofilakse s tarčno vrednostjo anti-Xa 0,4-0,5 IE/ml.

Uporaba nizkih odmerkov AK tromboprofilakse hkrati z antiagregacijskim 
zdravljenjem z Aspirinom ${ }^{\circledR} \mathrm{v}$ odmer$\mathrm{ku} \leq 5 \mathrm{mg} / \mathrm{kg} / \mathrm{dan}$ zaradi prisotnosti srčnih nepravilnosti ali značilnosti Kawasakijevi podobne bolezni pri otrocih z MIS-C ob odsotnosti drugih dejavnikov tveganja za krvavitev verjetno ne poveča tveganja za klinično pomembne krvavitve.

\section{Obravnava otrok z znano prirojeno trombofilijo}

Otroci s prirojeno trombofilijo imajo večje tveganje tromboze v stanjih, kot so daljša nepomičnost, huda dehidriranost ali drugi dejavniki, ki povečujejo tveganje tromboze. Individualno tveganje je pogojeno z vrsto trombofilije (Tabela 5) (22), zato svetujemo posvet s hematologom o uvedbi farmakološke AK tromboprofilakse glede na individualni znani trombofilni dejavnik in morebitne hkratne pridobljene trombofilne dejavnike, če za AK tromboprofilakso ni kontraindikacij. O umestnosti AK tromboprofilakse se $v$ teh primerih odločamo ne glede na to, ali otrok preboleva simptomatsko ali brezsimptomno okužbo s SARS-CoV-2, ter ne glede na to, ali je zaradi okužbe hospitaliziran ali obravnavan ambulantno.

Pri okužbi s SARS-CoV-2 s težkim potekom sta potrebni nepretrgano klinično in laboratorijsko spremljanje pojava morebitne tromboze ter zgodnje prepoznavanje DIK (vsakodnevno določanje hemograma, APTČ, PČ, TČ, fibrinogena, AT in D-dimera).

\section{Obravnava otrok in mladostnikov s prirojeno motnjo strjevanja krvi}

Otroci in mladostniki s prirojeno motnjo strjevanja krvi (MSK) morajo biti ob obravnavi okužbe SARS-CoV-2 deležni enake oskrbe kot oseba brez MSK. Potrebno je tesno sodelovanje s hematologom, ki nadzira hemostatski del obravnave glede na potrebe po dodatni hemostatski podpori ob invazivnih posegih, intenziviranju zdravljenja glede na potek okužbe ter preprečevanju ali zdravljenju morebitnih zapletov s krvavitvijo ali trombozo.

Ker so prirojene motnje strjevanja krvi redke in ker za zdravljenje MSK uporabljamo tudi nova zdravila, ki ne temeljijo na nadomeščanju manjkajočega faktorja (F) strjevanja krvi, je ob pričetku obravnave otroka s prirojeno MSK z okužbo s SARS-CoV-2 nujen takojšen posvet s pediatrom hematologom. Med prirojenimi MSK so najpogostejše von Willebrandova bolezen (VWB) ter hemofilija ( $\mathrm{H}$ ) A in hemofilija $B$, zato so specifična terapevtska priporočila, prirejena po priporočilih za odrasle osebe s hemofilijo (23), v večini naslovljena na omenjeni skupini bolnikov. Za otroke z drugimi, redkejšimi MSK veljajo enaka splošna priporočila kot za otroke $s$ VWB ter $\mathrm{HA}$ in HB, zdravljenje pa odrejamo za posameznega bolnika posebej.

Pri otrocih s prirojeno MSK moramo ob potrditvi okužbe s SARS-CoV-2 nadaljevati z ustaljenim profilaktičnim nadomestnim zdravljenjem s pripravkom FVIII/FIX/VWF ali monoklonskim protitelesom (emicizumab, Hemlibra ${ }^{\circledR}$ ), če ga otrok redno prejema.

1. V primeru težjega poteka okužbe $s$ SARS-CoV-2 so potrebni nepretrgano klinično in laboratorijsko spremljanje pojava morebitne krvavitve ali tromboze, zgodnja prepoznava DIK (dnevne določitve hemograma, APTČ, PČ, TČ, fibrinogena, AT in D-dimera) ter spremljanje ustreznosti nadomestnega zdravljenja s pripravki faktorjev strjevanja krvi (FVIII pri HA, FIX pri HB in vWF pri VWB).

2. Če je otrok s prirojeno MSK hospitaliziran zaradi hudega poteka okužbe s SARS-CoV-2, je potrebno intenziviranje nadomestnega zdravljenja s pripravki faktorjev (vzdrževanje aktivnosti FVIII/ FIX/VWF med $30 \%$ in $60 \%$ ). V enoti intenzivne terapije moramo pripravke odrejati kot za primer hude poškodbe (vzdrževanje aktivnosti FVIII/FIX/vWF med $80 \%$ in $100 \%$ ), če jih je dotlej prejemal, ali razmisliti o uvedbi prehodnega preventivnega zdravljenja, če ga dotlej ni prejemal.

3. V primeru kakršnega koli invazivnega posega (odvzem krvi za plinsko analizo, nastavitev centralnega venskega katetra (CVK) ali arterijskega katetra, kateterizacija mehurja, intubacija, lumbalna punkcija itd.) je potrebno v izogib iatrogeni krvavitvi odrediti dodatni odmerek pripravka FVIII/FIX/VWF ali drugega hemostatskega pripravka.

4. Pri odraslih bolnikih s prirojeno MSK in težko potekajočo okužbo s SARS-CoV-2, ki imajo povišane vrednosti D-dimera, priporočamo AK tromboprofilakso/zdravljenje z NMH hkrati z neprekinjenim nadomestnim zdravljenjem s pripravki faktorjev strjevanja krvi. Analogno svetujemo individualno presojo o uvedbi NMH v profilaktičnem odmerku tudi za otroke z MSK glede na vrsto in stopnjo osnovne MSK, tveganje krvavitve in bolnikove starosti.

Posebno opozorilo velja za otroke s HA, ki prejemajo monoklonsko protitelo (emicizumab, Hemlibra ${ }^{\circledR}$ )

Jasnih podatkov o povečanem tveganju tromboze ali razvoja koagulopatije pri osebah s HA, ki ob okužbi s SARS-CoV-2 prejemajo emicizumab (Hemlibra ${ }^{\circledR}$ ), zaradi majhnega števila bolnikov ni, zato je potreben skrben nadzor pojava krvavitve ali tromboze s kliničnim spremljanjem in laboratorijskimi preiskavami (hemogram, APTČ, $P C ̌$, fibrinogen, AT in D-dimer) (24).

Opozarjamo, da so vrednosti nekaterih enostopenjskih testov strjevanja krvi, s katerimi ocenjujemo koagulacijo in nadzorujemo DIK, zaradi prisotnosti emicizumaba (Hemlibra ${ }^{\circledR}$ ) lažno normalne, saj je vrednost APTČ lažno skrajšana. Zato je v primeru kakršnega koli invazivnega posega v izogib krvavitve potreben posvet s hematologom glede morebitnega predpisa dodatnega odmerka zdravila. 


\begin{tabular}{|c|c|c|c|}
\hline & \multirow{2}{*}{$\begin{array}{l}\text { Starost }<2 \text { meseca } \\
\text { odmerjanje } \\
\text { na } 12 \text { ur }\end{array}$} & \multicolumn{2}{|l|}{ Starost $>2$ meseca } \\
\hline & & $\begin{array}{l}\text { odmerjanje } \\
\text { na } 12 \text { ur }\end{array}$ & $\begin{array}{l}\text { odmerjanje } \\
\text { na } 24 \text { ur* }\end{array}$ \\
\hline Preventivni odmerki & $\begin{array}{l}0,75 \mathrm{mg} / \mathrm{kg} \\
\text { na odmerek } \\
\text { na } 12 \text { ur s.c. }\end{array}$ & $\begin{array}{l}0,5 \mathrm{mg} / \mathrm{kg} \\
\text { na odmerek } \\
\text { na } 12 \mathrm{ur} \mathrm{s.c.} \\
\text { (največji odmerek } \\
30 \mathrm{mg} \text { ) }\end{array}$ & $\begin{array}{l}1 \mathrm{mg} / \mathrm{kg} \text { s.c. } \\
\text { (največji odmerek } \\
40 \mathrm{mg} \text { ) }\end{array}$ \\
\hline Terapevtski odmerki & $\begin{array}{l}1,5 \mathrm{mg} / \mathrm{kg} \\
\text { na odmerek } \\
\text { na } 12 \text { ur s.c. }\end{array}$ & $\begin{array}{l}1 \mathrm{mg} / \mathrm{kg} \\
\text { na odmerek } \\
\text { na } 12 \text { ur s.c. }\end{array}$ & 1,5 mg/kg s.c. \\
\hline
\end{tabular}

TABELA 6: PRIPOROČENI PREVENTIVNI IN TERAPEVTSKI ODMERKI ANTIKOAGULACIJSKEGA ZDRAVLJENJA Z ENOKSAPARINOM (CLEXANE $\left.{ }^{\oplus}\right)(25)$

TABLE 6: RECOMMENDED PREVENTIVE AND THERAPEUTIC DOSES OF ANTICOAGULANT THERAPY WITH ENOXAPARIN (CLEXANE ${ }^{\circledR}$ ) (25)

Opombe: *odmerjanje na 24 ur le po dogovoru s hematologom; \#Clexane - najpogosteje predpisovani pripravek nizkomolekularnega heparina pri otrocih in novorojenčkih; s.c. - subkutano.

\begin{tabular}{lll} 
& $\begin{array}{l}\text { Anti-Xa } \\
\text { (odmerjanje na 12 ur) }\end{array}$ & $\begin{array}{l}\text { Anti-Xa } \\
\text { (odmerjanje na 24 ur) }\end{array}$ \\
\hline Preventivni odmerki & $0,1-0,3 \mathrm{IE} / \mathrm{ml}$ & - \\
\hline Terapevtski odmerki & $0,5-1,0 \mathrm{IE} / \mathrm{ml}$ & $1,0-2,0 \mathrm{IE} / \mathrm{ml}$
\end{tabular}

TABELA 7: ŽELJENA RAVEN ANTI-XA ZA ANTIKOAGULACIJSKO ZDRAVLJENJE Z NIZKOMOLEKULARNIM HEPARINOM (25).

TABLE 7: TARGET LEVEL OF ANTI-XA FOR ANTICOAGULANT TREATMENT WITH LOW MOLECULAR WEIGHT HEPARIN (25).
1. Emicizumaba $\left(\mathrm{Hemlibra}^{\circledR}\right)$ ne ukinjamo. Ob tem se moramo zavedati, da je zdravilo po ukinitvi jemanja v telesu prisotno še nekaj mesecev, saj je njegov razpolovni čas približno $30 \mathrm{dni}$.

2. Zaradi stalne aktivacije koagulacije, ki je posledica mehanizma delovanja emicizumaba (Hemlibra ${ }^{\circledR}$ ), se o uvedbi AK tromboprofilakse odločamo individualno glede na trenutno prisotno tveganje krvavitve (glede na potek okužbe, raven hemostatske zaščite, morebitne invazivne posege) ali tromboze ter morebitne druge pridružene pridobljene trombofilne dejavnike (Tabela 1).

3. Potrebno je vsakodnevno določanje hemograma, APTČ, PČ, fibrinogena, AT in D-dimera za spremljanje morebitne aktivacije koagulacije.

4.Potrebna je vsakodnevna ocena, ali bolnik glede na potek bolezni in potrebe po specifičnih invazivnih ukrepih (odvzem krvi za plinsko analizo, nastavitev CVK ali arterijskega katetra, kateterizacija mehurja, intubacija, lumbalna punkcija itd.) potrebuje dodatno nadomestno zdravljenje s faktorjem strjevanja krvi:

- bolnik s hemofilijo A brez inhibitorjev naj prejme rFVIII (npr. Nuwiq ${ }^{\circledR}$ ali Elocta $^{\circledR}$ );

- bolnik s hemofilijo A z inhibitorji naj prejme rFVIla (Novoseven ${ }^{\circledR}$ ).

Zaradi znane interakcije med emicizumabom in koncentratom aktiviranega protrombinskega kompleksa (aPCC; Feiba ${ }^{\circledR}$ ) pri bolnikih s hemofilijo $A$ z inhibitorji prednostno uporabljamo rFVIla, aPCC pa le izjemoma.

\section{Otroci, ki imajo nameščen centralni venski kateter}

Otroke s CVK obravnavamo individualno. O uvedbi farmakološke antikoagulacijske tromboprofilakse razmislimo pri otrocih s CVK, ki so utrpeli ponavljajoče se tromboze, potem ko pretehtamo tveganje krvavitve. Pri ostalih 
otrocih individualno preučimo resnost poteka okužbe s SARS-CoV-2 in hkratne dejavnike tveganja TED ter razmislimo o uvedbi AK tromboprofilakse, če sta pri otroku s CVK prisotna vsaj dva dodatna dejavnika tveganja TED (Tabela 1).

\section{Farmakološka antikoagulantna tromboprofilaksa ali zdravljenje}

Pri otrocih in mladostnikih za farmakološko AK tromboprofilakso ali zdravljenje svetujemo uporabo NMH. Največ izkušenj pri predpisovanju $\mathrm{NMH}$ pri otrocih, vključno z obdobjem novorojenčka, imamo z enoksaparinom (Clexane ${ }^{\circledR}$ ). Neposredne peroralne antikoagulante zaradi omejenih izkušenj pri otrocih odsvetujemo.

Pred uvedbo AK zdravljenja (priporočeni odmerki so navedeni v Tabeli 6) je potrebno določiti hemogram, APTČ, PČ, TČ, fibrinogen, AT, D-dimer ter ureo in kreatinin v serumu, s čimer izključimo morebitno pridruženo bolezen kostnega mozga, prirojeno ali pridobljeno motnjo strjevanja krvi ter ledvično insuficienco. Pri slednji sta zaradi nevarnosti akumulacije $\mathrm{NMH}$ potrebni prilagojeno odmerjanje ter skrbno laboratorijsko spremljanje učinka zdravila ali uporaba nefrakcioniranega heparina.

Pri otrocih sta $\mathbf{v}$ nasprotju z odraslimi farmakokinetika in farmakodinamika NMH slabše predvidljivi, zato je potrebno laboratorijsko spremljanje učinkovitosti AK tromboprofilakse/ zdravljenja z določanjem aktivnosti anti-Xa (Tabela 7), ki ga določimo:

- 3-4 ure po 2. ali 3. odmerku enoksaparina (pri odmerjanju na 12 ur);

- 4-6 ur po 4. odmerku enoksaparina (pri odmerjanju na 24 ur) (24).

- Željeno raven anti-Xa za AK tromboprofilakso in zdravljenje navajamo v Tabeli 7 (25).
V primeru krvavitve, trombocitopenije (št. trombocitov $<50 \times 10^{9} / \mathrm{l}$ ), hipofibrinogenemije (fibrinogen $<1,0 \mathrm{~g} / \mathrm{l}$ ) in podaljšanih vrednosti APTČ, ki so lahko posledica prisotnosti antifosfolipidnega sindroma, je potreben posvet s hematologom.

Nadaljevanje antikoagulantne tromboprofilakse po odpustu $\mathbf{v}$ domačo oskrbo je indicirano $v$ primeru še vedno povišanih vrednosti D-dimera ob odpustu ( $\geq 2$-krat nad pražnimi vrednostmi) in v drugih primerih po individualni presoji po posvetu $s$ hematologom v trajanju še 7-14 dni po odpustu.

Terapevtske ali profilaktične odmerke AK zdravil naj prejemajo otroci, ki so tovrstno zdravljenje/profilakso prejemali že pred bolnišničnim zdravljenjem zaradi drugih indikacij. Terapevtske odmerke AK zdravil naj prejemajo tudi otroci z utemeljenim sumom za TED do opravljenih preiskav za potrditev TED.

Takojšnje slikovne preiskave ob sumu na TED ali pljučno embolijo (UZ dopplerska preiskava žilja ali CT-angiografija pljuč) pred pričetkom antikoagulacijskega zdravljenja niso nujno potrebne, jih pa opravimo takoj, ko je mogoče. Pretehtamo tveganje ob transportu nestabilnega kritično bolnega otroka, tveganje za prenos okužbe med transportom na osebje ter možne logistične težave pri transportu in izvedbi slikovnih preiskav. Slikovne preiskave opravimo tudi ob odsotnosti kliničnih znakov tromboze ob vztrajno naraščajočih vrednostih D-dimera, kliničnega poslabšanja ali višji oceni na točkovniku za DIK po posvetu s hematologom, da bi našli morebitne klinično tihe TED. Ob potrditvi TED antikoagulacijsko zdravljenje intenziviramo ne glede na to, da napovedna vrednost točkovnika za DIK in napovedna vrednost naraščajočih vrednosti D-dimera pri otrocih trenutno nista jasni. O jasni DIK govorimo, če $s$ točkovnikom pri bolniku dosežemo vsaj 5 točk (4).

\section{Zaključek}

Med okužbo s SARS-CoV-2 lahko otroka ali mladostnika ogrožajo trombembolični dogodki, koagulopatija, povezana z okužbo s SARS-CoV-2, in DIK, zato je med hospitalizacijo pomembno aktivno nepretrgano klinično in laboratorijsko spremljanje morebitnega razvoja zapletov. Dodatna pozornost je potrebna pri obravnavi otrok s kronično boleznijo, prirojeno motnjo strjevanja krvi in prirojeno trombofilijo ter pri obravnavi otrok $z$ vstavljenim CVK, tudi če jih obravnavamo ambulantno.

Pri otrocih, ki prebolevajo MIS-C, ob odsotnosti kontraindikacij svetujemo uvedbo antikoagulantne tromboprofilakse.

\section{Literatura}

1. Toshiaki I, Jerrold HL, Marcel L, Jecko T. Coagulopathy in COVID-19. J Thromb Haemost 2020; 18(9): 2103-9.

2. Zhu J, Ji P, Pang J, Zhong Z, Li H, He C, Zhang J, Zhao C. Clinical characteristics of 3062 COVID-19 patients: A meta-analysis. J Med Virol 2020; 92(10): 1902-14.

3. Diorio C, McNerney KO, Lambert M, Paessler $M$, Anderson EM, Henrickson SE, et al. Evidence of thrombotic microangiopathy in children with SARS-CoV-2 across the spectrum of clinical presentations. Blood Adv 2020; 4(23): 6051-63.

4. Taylor FB Jr, Toh CH, Hoots WK, Wada H, Levi M; Scientific Subcommittee on Disseminated Intravascular Coagulation (DIC) of the International Society on Thrombosis and Haemostasis (ISTH). Towards definition, clinical and laboratory criteria, and a scoring system for disseminated intravascular coagulation. Thromb Haemost 2001; 86(5): 1327-30.

5. Dong $Y$, Mo $X$, Hu Y, Qi X, Jiang F, Jiang $X$, Tong S. Epidemiology of COVID-19 among children in China. Pediatrics 2020; 145(6): e20200702.

6. Riphagen S, Gomez X, Gonzalez-Martinez C, Wilkinson N, Theocharis P. Hyperinflammatory shock in children during COVID-19 pandemic. Lancet 2020; 395(10237): 1607-8.

7. Dufort EM, Koumans EH, Chow EJ, Rosenthal EM, Muse A, Rowlands J, et. al. New York State and Centers for Disease Control and Prevention Multisystem Inflammatory Syndrome in Children Investigation Team. Multisystem Inflammatory Syndrome in Children in New York State. N Engl J Med 2020; 383(4): 347-58.

8. Feldstein LR, Rose EB, Horwitz SM, Collins JP, Newhams MM, Son MBF, et.al. Multisystem Inflammatory Syndrome in U.S. Children 
and Adolescents. N Engl J Med 2020; 383(4): 334-46.

9. Iba T, Levy JH, Levy M, Connors JM, Thachil J. Coagulopathy of coronavirus disease 2019. Crit Care Med 2020; 48: 1358-64.

10. Del Borrello G, Giraudo I, Bondone C, Denina M, Garazzino S, Linari C, et. al. SARS-COV2-associated coagulopathy and thromboembolism prophylaxis in children: A single-center observational study. J Thromb Haemost 2021; 19(2): 522-30.

11. Goldenberg NA, Sochet A, Albisetti M, Biss $\mathrm{T}$, Bonduel M, Jaffray J, et. al. Pediatric/Neonatal Hemostasis and Thrombosis Subcommittee of the ISTH SSC. Consensus-based clinical recommendations and research priorities for anticoagulant thromboprophylaxis in children hospitalized for COVID-19-related illness. J Thromb Haemost 2020; 18(11): 3099-3105.

12. Mariasanta Napolitano, Giorgia Saccullo Marco Marietta' Monica Carpenedo, Giancarlo Castaman et al. Platelet cut-off for anticoagulant therapy in thrombocytopenic patients with blood cancer and venous thromboembolism: an expert consensus Blood Transfus 2019; 17(3): 171-80.

13. Branchford BR, Mourani P, Bajaj L, Manco-Johnson M, Wang M, Goldenberg NA. Risk factors for in-hospital venous thromboembolism in children: a case-control study employing diagnostic validation. Haematologica 2012; 97(4): 509-15.

14. Loi M, Branchford B, Kim J, Self C, Nuss R. COVID-19 anticoagulation recommendations in children. Pediatr Blood Cancer 2020; 67(9): e28485.

15. Young $E$. The anti-inflammatory effects of heparin and related compounds. Thromb Res 2008; 122(6): 743-52

16. Górski A, Wasik M, Nowaczyk M, Korczak-Kowalska G. Immunomodulating activity of heparin. FASEB 1991; 5(9): 2287-91.

17. Ma J, Bai J. Protective effects of heparin on endothelial cells in sepsis. Int J Clin Exp Med 2015; 8(4): 5547-52.

18. Haller H. Endothelial function. General considerations. Drugs 1997; 53(Suppl 1): 1-10.

19. Haller H. Modulation of endothelial function: strategy for long-term cardiovascular protection. J Hypertens Suppl 1996; 14: S27-32.

20. PMIS-TS- SGH Guideline for the management of Paediatric multisystem inflammatory syndrome temporally associated with COVID-19, St George NHS trust, maj 2020, Ver 4; dosegljivo na https://www.rcpch.ac.uk.

21. Faganel Kotnik B, Zajc Avramovič M, Kitanovski L, Avčin T: Prophylactic anticoagulation: comment on the American College of Rheumatology Guidance for Management of Multisystem Inflammatory Syndrome in Children. Arthritis Rheumatol 2021; 73(7): 1341-2.

22. Kurnik K, Bidlingmaier C. Gerinnungsstorunggen im Kindersalter. Diagnostik und Therapie-auf einen Blick. 2008 Ligatur. ISBN 978-3-94040700-9, stran 19.

23. Hermans C, Lambert C, Sogorb A, Wittebole $X$, Belkhir L, Yombi JC. In-hospital management of persons with haemophilia and COVID-19: Practical guidance. Haemophilia 2020; 26(5): 768-72.
24. Hemlibra - Important Safety Information \& Indication; dosegljivo na https://www.hemlibra. com/hcp/safety.html.

25. Tschudy MM, Asrcara KM. The Harriet Lane Handbook, 2012, 19. izdaja, Elsevier, stran 780-2. doc. dr. Barbara Faganel Kotnik, dr. med. (kontaktna oseba/contact person) Klinični oddelek za otroško hematologijo in onkologijo, Pediatrična klinika, Univerzitetni klinični center Ljubljana, Bohoričeva 20, 1000 Ljubljana, Slovenija e-naslov: barbara.faganel@gmail.com

doc. dr. Alenka Trampuš Bakija, univ. dipl. biol., spec. med. biokem.

Klinični inštitut za specialno laboratorijsko diagnostiko, Pediatrična klinika, Univerzitetni klinični center Ljubljana, Ljubljana, Slovenija

prof. dr. Tadej Avčin, dr. med. Klinični oddelek za otroško alergologijo, revmatologijo in klinično imunologijo, Pediatrična klinika, Univerzitetni klinični center Ljubljana, Ljubljana in Univerza v Ljubljani, Medicinska fakulteta, Ljubljana, Slovenija

doc. dr. Lidija Kitanovski, dr. med. Klinični oddelek za otroško hematologijo in onkologijo, Pediatrična klinika, Univerzitetni klinični center Ljubljana, Ljubljana, Slovenija

prispelo / received: 13.3 .2021 sprejeto / accepted: 14. 8. 2021

Faganel Kotnik B, Trampuš Bakija A, et.al. Nacionalna priporočila za antikoagulacijsko tromboprofilakso otrok in mladostnikov z okužbo SARS-CoV-2. Slov Pediatr 2021; 28(3): 123-129. https://doi.org/10.38031/slovpediatr-2021-3-02. 